doi: $10.2306 /$ scienceasia1513-1874.2014.40.053

\title{
Determination of arsenic in chilli and tomato grown in North East Thailand
}

\author{
Nittaya Thaharn ${ }^{\mathrm{a}}$, Suchila Techawongstien ${ }^{\mathrm{b}}$, Saksit Chanthai ${ }^{\mathrm{a}, *}$ \\ a Department of Chemistry and Centre of Excellence for Innovation in Chemistry, Faculty of Science, \\ Khon Kaen University, Khon Kaen 40002 Thailand \\ b Department of Plant Science and Agricultural Resources, Faculty of Agriculture, Khon Kaen University, \\ Khon Kaen 40002 Thailand
}

${ }^{*}$ Corresponding author, e-mail: sakcha2@kku.ac.th

Received 4 Apr 2013

Accepted 14 Dec 2013

\begin{abstract}
Heavy metals in edible fruits constitute a health hazard. We present an analytical procedure for determining inorganic arsenic (As) species in hot chilli pepper and tomato fruits at the red-ripe stage using microwave assisted digestion (MAD) followed by flow injection-hydride generation atomic absorption spectrometry (FI-HGAAS). The optimum conditions for the acid digestion method and arsenic hydride $\left(\mathrm{AsH}_{3}\right)$ determination were studied in detail. The plant sample $(0.5 \mathrm{~g})$ was digested with $5 \mathrm{ml}$ of concentrated nitric acid by MAD programmed at $900 \mathrm{~W}$ for $35 \mathrm{~min}$. Arsenite, As(III), in the acid digests could only be analysed by FI-HGAAS using $1 \%(\mathrm{v} / \mathrm{v}) \mathrm{HCl}$ as a carrier solution and $0.5 \%(\mathrm{w} / \mathrm{v}) \mathrm{NaBH}_{4}$ in $0.04 \%(\mathrm{w} / \mathrm{v}) \mathrm{NaOH}$ as a reducing agent, while total As content was determined after pre-reduction of arsenate, $\mathrm{As}(\mathrm{V})$, to As(III) with $2 \%(\mathrm{w} / \mathrm{v})$ thiourea prior to measurement. The concentration of As(V) was then calculated as the difference between total As and As(III). Detection limits for As(III) and As(V) were 0.004 and $0.006 \mu \mathrm{g} / 1$, respectively. The relative standard deviation of the data was less than $5 \%(n=10)$. The recovery of the samples spiked with $10 \mu \mathrm{g} / \mathrm{l}$ As was $98-103 \%$. The proposed method was applied to determine traces of As in six varieties of hot chilli pepper $(0.55-0.88 \mu \mathrm{g} / \mathrm{g}$ As(III) and $0.22-0.93 \mu \mathrm{g} / \mathrm{g} \mathrm{As}(\mathrm{V}))$ and seven varieties of tomato (0.36-0.64 $\mu \mathrm{g} / \mathrm{g}$ As(III) and 0.22-0.60 $\mu \mathrm{g} / \mathrm{g}$ As(V)) samples.
\end{abstract}

KEYWORDS: speciation analysis, hydride generation, microwave digestion, atomic absorption spectrometry

\section{INTRODUCTION}

Heavy metals concern us because of occupational or residential exposure. Small amounts of the elements are common in our environment and diet and are necessary for good health, but large amounts of any of them may cause acute or chronic toxicity. The toxicity of some heavy metals can reduce mental and central nervous function, and deteriorate blood components, lungs, kidneys, liver, and other vital organs. Long-term exposure may result in slowly progressing physical, muscular, and neurological degenerative deficits ${ }^{1,2}$.

Among toxic metals, arsenic (As) is still an interesting one as it is widely distributed in the environment, originating either from As in the soil parent material or from discharge of As onto land as a result of human activities. Consequently, people and livestock are being exposed to As via contamination of drinking water and consumption of food grown in the As-contaminated soil or irrigated with Ascontaminated water. Understanding how As is taken up by plants and subsequently transformed in plant tissue is, therefore, essential for estimating the risks posed to human and wildlife populations ${ }^{3}$. In aerobic soils, arsenate, $\mathrm{As}(\mathrm{V})$, is the most thermodynamically stable and hence dominant species. The uptake of As(V) by plants has been studied extensively. The transformation of $\mathrm{As}(\mathrm{V})$ in the plant tissue and its controlling factors and the subsequent translocation of As species from roots to shoots are, however, not well understood. In terrestrial plants, both organic and inorganic As species have been found with the inorganic species of arsenate, As(V) and arsenite, As(III), being the most dominant ${ }^{4-8}$. Biosorption of As(III) and $\mathrm{As}(\mathrm{V})$ from aqueous solution by various sources of algae, fungus, or lichen biomass has been reported in terms of equilibrium and kinetics studies ${ }^{9-12}$. This transformation of the inorganic arsenic species can be implemented into the plant tissue. Generally, only small levels of organic As species have been detected in plant tissue; however, it is unclear whether these species are a product of transformation in plants or whether they are simply taken up from the soil ${ }^{3,8}$. The residual contents of As and its inorganic speciation in common edible fruits like hot chilli pepper and 
tomato varieties have not been reported. This novel finding was achieved by an optimization study on the sample treatment using microwave assisted digestion (MAD) prior to measurement by flow injectionhydride generation atomic absorption spectrometry (FI-HGAAS). Thus simple analytical procedures for sample preparation and measurement of inorganic arsenic species are needed for routine analysis with high sensitivity, selectivity, accuracy and precision including short analysis time.

This study aimed to investigate optimum conditions for the determination of As(III) and As(V) using FI-HGAAS and suitable procedure for sample preparation using MAD method to determine inorganic As species in hot chilli pepper and tomato samples ${ }^{13,14}$

\section{MATERIALS AND METHODS}

\section{Chemicals}

All reagents and solutions were prepared from analytical reagent grade of chemicals using de-ionized water (Milli Q Millipore $18.2 \mathrm{M} \mathrm{cm}^{-1}$ resistivity) by water purification system (Simplicity 185, Millipore Corporation, USA). The atomic absorption spectroscopy standard solution (1000 mg/l) of As(III) was obtained from Spectrosol (England). The stock standard solution of $\mathrm{As}(\mathrm{V})$ was prepared by dissolving $\mathrm{AsHNa}_{2} \mathrm{O}_{4} \cdot 7 \mathrm{H}_{2} \mathrm{O}$ from Sigma-Aldrich (USA) in $2 \%$ (v/v) $\mathrm{HNO}_{3}$. Sodium tetrahydroborate from Ajax Fine Chem (Australia) dissolved in sodium hydroxide from Carlo Erba (Italy) was employed. Hydrochloric acid solution was prepared from $37 \%$ (w/v) $\mathrm{HCl}$ (Lab Scan Asia, Thailand). Nitric acid (Lab Scan Asia, Thailand), thiourea (BDH laboratory supplies, UK), potassium iodide (Carlo Erba, Italy), potassium bromine (Asia Pacific Specialty Chemicals Ltd., Australia), ascorbic acid (Carlo Erba, Italy) were also used.

\section{Instruments}

Measurement of As was performed using an atomic absorption spectrometer of the Perkin Elmer Instruments AAnalyst 100 equipped with a flow injection analysis system (FIAS-100, Perkin Elmer Instruments, USA), used for continuous flow-hydride generation. The FIAS-100 consists of a peristaltic pump, five-port valve with $500 \mu$ sample loop and a regulated gas control. Argon gas was used as carrier gas for the transposition of arsine $\left(\mathrm{AsH}_{3}\right)$ from the gas-liquid separator to the electrically heated quartz tube $\left(900^{\circ} \mathrm{C}\right)$. For AAS using As electrodeless discharge lamp (EDL, $380 \mathrm{~mA}$ ), arsenic absorption line was detected at $193.7 \mathrm{~nm}$ with $0.7 \mathrm{~nm}$ slit width. Microwave assisted digestion (Anton Parr 3000, Austria) with 8 units of a high pressure PTFE vessel was used.

\section{Plant materials}

Hot chilli and tomato samples were collected randomly from natural cultivars which had been planted in horticulture fields without any supplement of chemical fertilizers at Department of Plant Science and Agricultural Resources, Khon Kaen University, Thailand. Six varieties of hot chilli commonly consumed, the so-called local Thai names; Jindanil 80, Numkaew Thong 80, Super Hot, Yodson Khem 80, Yodson Korat, and Huay Sithon belong to the same species of Capsicum annuum L. Seven varieties of tomato at red-ripe stage (consisting of three kinds of the plant breeding code as PD09, PS07, GD, and four local Thai names as Cherry Kham Kaen, Puang Thong, Morrakot Daeng, and Manee Siam) were obtained from pedigree selection of Lycopersicon esculentum Mill. These plants were grown during September 2011-February 2012. The plant samples were dried in an oven at $60^{\circ} \mathrm{C}$ for $48 \mathrm{~h}$ and ground in a kitchen grinder (Philips, Indonesia) to pass a 35-mesh sieve. The ground samples were stored in plastic bags and stored in desiccator ${ }^{15,16}$. Moisture content of the samples was determined by a drought oven set at $105^{\circ} \mathrm{C}$ until a constant weight was obtained. Dry matter of the samples was calculated as dry weight from the moisture content. The results are reported based on dry weight basis ${ }^{17}$.

\section{Microwave assisted digestion}

The ground plant sample $(0.5 \mathrm{~g})$ was accurately weighed into a high pressure PTFE vessel and $5 \mathrm{ml}$ of concentrated $\mathrm{HNO}_{3}$ was added. The vessel was closed and placed inside the microwave oven unit. It was then heated following a one-stage digestion programmed at $900 \mathrm{~W}$ for $35 \mathrm{~min}$. The acid-digests solution was cooled and diluted to $25 \mathrm{ml}$ final volume in a volumetric flask with $10 \%(\mathrm{v} / \mathrm{v}) \mathrm{HCl}$. The method recovery was done by spiking $10 \mu \mathrm{g} / \mathrm{l}$ each of As(III) and $\mathrm{As}(\mathrm{V})$ into the ground sample before digestion by MAD.

\section{Analytical methods for As(III), As(V), and total As}

Standard solutions $(10 \mu \mathrm{g} / \mathrm{l})$ of $\mathrm{As}(\mathrm{III})$ and $\mathrm{As}(\mathrm{V})$ were prepared by a step dilution with $10 \%(\mathrm{v} / \mathrm{v}) \mathrm{HCl}$ from its stock solution $(1 \mathrm{~g} / \mathrm{l})$. The working solution for both As species was prepared daily. The calibration curve $(1.0,2.0,3.0,4.0$, and $5.0 \mu \mathrm{g} / \mathrm{l})$ for As(III) determination was established, using the standard solution prepared in $10 \%(\mathrm{v} / \mathrm{v}) \mathrm{HCl}$, by plotting the absorbance obtained versus their concentration. Also for $\mathrm{As}(\mathrm{V})$, the standard curve was done in the same 
manner using the working solution of $\mathrm{As}(\mathrm{V})$ including $1 \mathrm{ml}$ of $2 \%(\mathrm{w} / \mathrm{v})$ thiourea as a pre-reduction agent. In addition, total inorganic As standard solution was prepared by a mixture of each appropriate contents of both As(III) and As(V) standard solution including $2 \%(\mathrm{w} / \mathrm{v})$ thiourea.

\section{Optimization conditions for As determination by FI-HGAAS}

An $\mathrm{HCl}$ solution used as a carrier solution was prepared by an appropriate dilution of concentrated $\mathrm{HCl}$ with de-ionized water. The carrier solution was investigated by varying the concentration of $\mathrm{HCl}$ in the range $0.5-9 \%(\mathrm{v} / \mathrm{v}) . \mathrm{A} \mathrm{NaBH}_{4}$ solution was prepared fresh daily by dissolving an accurate amount of $\mathrm{NaBH}_{4}$ in dilute $\mathrm{NaOH}$ solution and used as a reducing agent. The reducing agent was a major factor for the arsine formation which was studied by varying the concentration of $0.1-1 \%(\mathrm{w} / \mathrm{v})$ of $\mathrm{NaBH}_{4}$ dissolved in the base solution. In addition, the concentration of $\mathrm{NaOH}$ for stabilizing the reducing agent was also optimized between 0.01 and $0.09 \%$ (w/v).

\section{Effect of pre-reduction agents on $\operatorname{As}(\mathbf{V})$ and total As determination}

Some selected pre-reducing agents including potassium iodide $(\mathrm{KI})$, potassium bromine $(\mathrm{KBr})$, thiourea, ascorbic acid solutions in the concentration range 1.0 $6 \%(\mathrm{w} / \mathrm{v})$ were prepared by dissolving a required amount of $\mathrm{KI}, \mathrm{KBr}$, thiourea, and ascorbic acid in deionized water. For mixture of the pre-reducing agents, KI plus ascorbic acid and KI plus thiourea were prepared by dissolving KI with $0.3 \%$ (v/v) ascorbic acid and $2 \%(\mathrm{v} / \mathrm{v})$ thiourea, respectively. For the determination of $\mathrm{As}(\mathrm{V})$, aliquots $(2 \mathrm{ml})$ of the acid digested solution was pipetted into a $10 \mathrm{ml}$ volumetric flask. Then $1 \mathrm{ml}$ of $2 \%(\mathrm{w} / \mathrm{v})$ thiourea solution was added and diluted with $10 \%(\mathrm{v} / \mathrm{v}) \mathrm{HCl}$ to the final volume. This solution was left to stand for $15 \mathrm{~min}$ prior to analysis. The concentration of total inorganic As, As(III) plus As(V), was obtained, if the As(III) originally presented in the solution. Thus the As(V) content in the sample can be calculated by the difference between the original content of As(III) and sum of total inorganic As one. It is noted that in case of the acid digestion of the plant sample, organoarsenic species were negligible.

\section{RESULTS AND DISCUSSION}

\section{Optimization conditions for FI-HGAAS}

Firstly, experiments were carried out to optimize the hydride generation (HG) conditions for the speciation
Table 1 Instrumental parameters and working conditions of As determination by FI-HGAAS.

\begin{tabular}{ll}
\hline Parameter & Condition \\
\hline Measurement mode & Absorbance \\
Slit width & $0.70 \mathrm{~nm}$ \\
Wavelength & $193.7 \mathrm{~nm}$ \\
Quartz tube temperature & $900{ }^{\circ} \mathrm{C}$ \\
Lamp current & $380 \mathrm{~mA}$ \\
Energy & 48 \\
$\mathrm{HCl} \mathrm{concentration}_{\mathrm{NaBH}_{4} \text { concentration }}$ & $1 \%(\mathrm{v} / \mathrm{v})$ \\
Purging gas & $0.5 \%(\mathrm{w} / \mathrm{v})$ in $0.04 \%(\mathrm{w} / \mathrm{v}) \mathrm{NaOH}$ \\
Sample loop & $70 \mathrm{ml} / \mathrm{min}$ argon \\
\hline
\end{tabular}

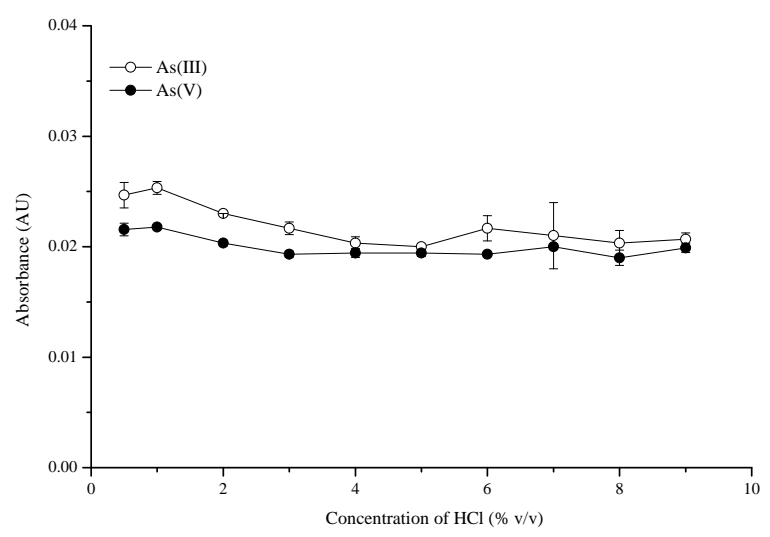

Fig. 1 Effect of $\mathrm{HCl}$ concentration on the absorbance of $\mathrm{As}(\mathrm{III})$ and $\mathrm{As}(\mathrm{V})$ in the presence of $0.5 \%(\mathrm{w} / \mathrm{v}) \mathrm{NaBH}_{4}$ in $0.04 \%$ (w/v) $\mathrm{NaOH}$.

analysis, since the performance of FI-HGAAS system will give rising in ultra-trace level with high sensitivity and selectivity. Such parameters for the HG conditions were optimized including various concentrations of $\mathrm{HCl}$ as carrier solution and $\mathrm{NaBH}_{4}$ in $\mathrm{NaOH}$ as reducing agent for both $\mathrm{As}(\mathrm{III})$ and $\mathrm{As}(\mathrm{V})$. Working conditions of As determination by FI-HGAAS are summarized in Table 1. Pre-reduction of As(V) to As(III) was necessary for the determination of As(V) and total inorganic arsenic.

\section{Effect of $\mathrm{HCl}$ concentration as carrier solution}

The influence of $\mathrm{HCl}$ concentration in carrier solution was investigated in the range $0.5-9 \%(\mathrm{v} / \mathrm{v})$ (Fig. 1). It was found that varying concentration of $\mathrm{HCl}$ did not produce much difference on absorbance. Lower concentration of $\mathrm{HCl}$ between 0.5 and $1 \%(\mathrm{v} / \mathrm{v})$ gave considerably higher absorbance, while higher concentrations of the acid did not improve the analytical signal and it would cause severe effervescence and splashing of solution droplets on the gas-liquid separator inner walls to fast reaction. Then about $1 \%(\mathrm{v} / \mathrm{v})$ $\mathrm{HCl}$ solution was chosen as the acid medium. 


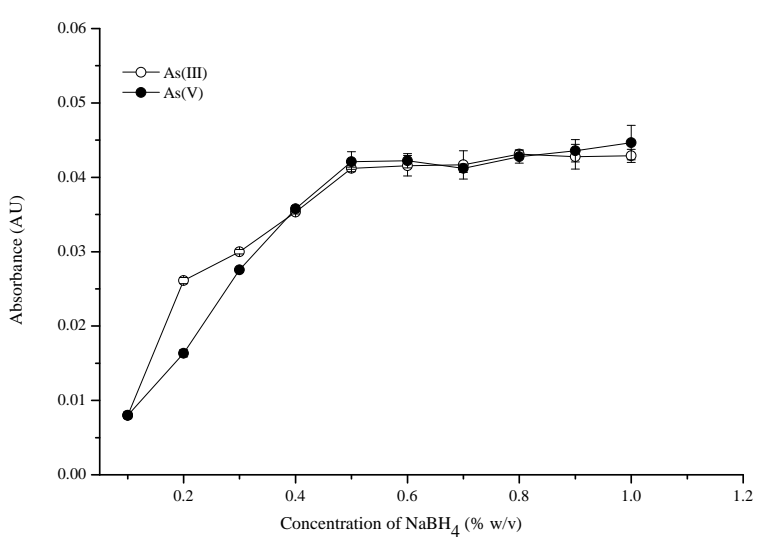

Fig. 2 Effect of $\mathrm{NaBH}_{4}$ concentration on the absorbance of $\mathrm{As}(\mathrm{III})$ and $\mathrm{As}(\mathrm{V})$ in the presence of $0.04 \%(\mathrm{w} / \mathrm{v}) \mathrm{NaOH}$ and $0.1 \%(\mathrm{w} / \mathrm{v}) \mathrm{HCl}$ as carrier solution.

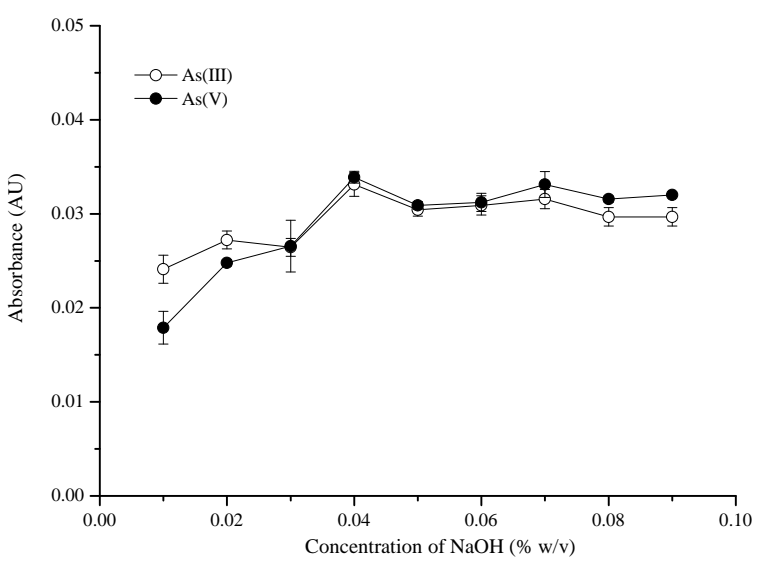

Fig. 3 Effect of $\mathrm{NaOH}$ concentration on the absorbance of $\mathrm{As}(\mathrm{III})$ and $\mathrm{As}(\mathrm{V})$ in the presence of $0.5 \%(\mathrm{w} / \mathrm{v}) \mathrm{NaBH}_{4}$ and $0.1 \%(\mathrm{w} / \mathrm{v}) \mathrm{HCl}$ as carrier solution.

\section{Effect of $\mathrm{NaBH}_{4}$ concentration as reducing agent}

The concentration of $\mathrm{NaBH}_{4}$ is an important parameter for arsine generation because it is formed in the present of hydrogen generated by $\mathrm{NaBH}_{4}$ in an acidic medium. It was found that the absorbance for As determination increased linearly when increasing the $\mathrm{NaBH}_{4}$ concentrations from $0.1-0.5 \%(\mathrm{w} / \mathrm{v})$, after that it tended to be constant (Fig. 2). Thus $0.5 \%$ (w/v) $\mathrm{NaBH}_{4}$ was preferably used for further experiment.

\section{Effect of $\mathrm{NaOH}$ concentration as auxiliary stabilizing the reducing agent}

To stabilize the $\mathrm{NaBH}_{4}$ solution, the concentration of $\mathrm{NaOH}$ was also investigated in the range $0.01-0.09 \%$ (w/v). From Fig. 3, the absorbance increased slightly when increasing of $\mathrm{NaOH}$ concentration between 0.01

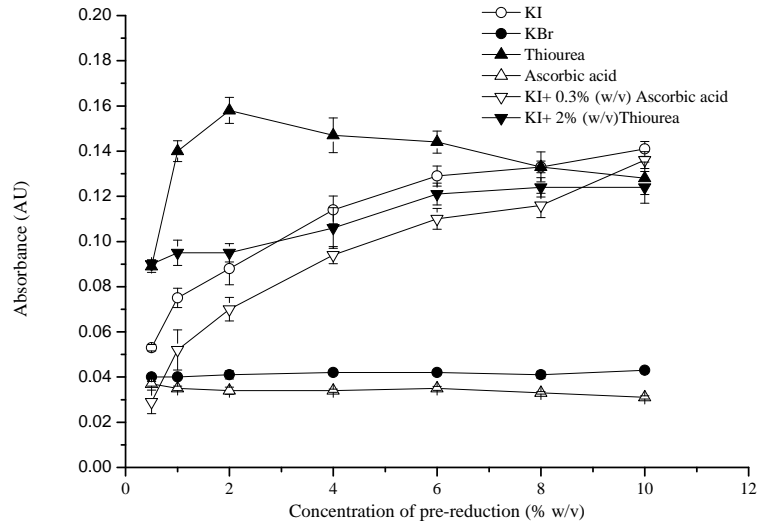

Fig. 4 Effects of pre-reducing agents on the absorbance of $\mathrm{As}(\mathrm{III})$ in the presence of $0.5 \%(\mathrm{w} / \mathrm{v}) \mathrm{NaBH}_{4}$ in $0.04 \%$ $(\mathrm{w} / \mathrm{v}) \mathrm{NaOH}$ as reducing agent and $0.1 \%(\mathrm{v} / \mathrm{v}) \mathrm{HCl}$ as carrier solution.

and $0.04 \%(\mathrm{w} / \mathrm{v})$, beyond that it had no change. Hence, $0.04 \%$ (w/v) $\mathrm{NaOH}$ was also important one as an auxiliary reagent for the reducing system.

\section{Effect of pre-reduction agent on $\mathrm{As}(\mathrm{V})$ to be As(III)}

Various types of pre-reducing agents had been used to reduce $\mathrm{As}(\mathrm{V})$ to be $\mathrm{As}(\mathrm{III})$ including $\mathrm{KI}^{18}, \mathrm{KBr}$, thiourea ${ }^{18}$, ascorbic acid, KI plus ascorbic acid ${ }^{19,20}$, and KI plus thiourea ${ }^{21}$ solutions. The concentration of the pre-reducing agent was investigated in the range $0.5-10 \%(w / v)(F i g .4)$. It was found that $2 \%(w / v)$ thiourea gave the highest absorbance among others in this experiment.

The optimized conditions for FI-HGAAS were therefore obtained as follows: $1 \%(\mathrm{v} / \mathrm{v}) \mathrm{HCl}$ as a carrier solution, and $0.5 \%(\mathrm{w} / \mathrm{v}) \mathrm{NaBH}_{4}$ in $0.04 \%(\mathrm{w} / \mathrm{v})$ $\mathrm{NaOH}$ as reducing agent. Pre-reduction of $\mathrm{As}(\mathrm{V})$ prior to the determination of As(III) was demonstrated by using $2 \%(\mathrm{w} / \mathrm{v})$ thiourea. Under this optimum condition of the instrument, limit of detection (LOD) and limit of quantification (LOQ) were calculated by showing the probability density function for normally distributed measurements of the blank, at the LOD defined as 3 standard deviations of the blank, and at the LOQ defined as 10 standard deviations of the blank. LOD and LOQ of FI-HGAAS for As detection were found to be $0.006 \mu \mathrm{g} / \mathrm{l}$ and $0.022 \mu \mathrm{g} / \mathrm{l}$, respectively.

\section{Sample preparation by MAD}

The sample preparation for chilli and tomato samples by using microwave assisted digestion was carried out. The optimum conditions for MAD were also investigated in detail in order to reduce the plant 
Table 2 Effect of the sample amounts on the recovery of spiked $10 \mu \mathrm{g} / \mathrm{l} \mathrm{As}(\mathrm{III})$ in chilli pepper and tomato samples.

\begin{tabular}{lcr}
\hline Amount of sample $(\mathrm{g})^{*}$ & Chilli pepper & \multicolumn{1}{c}{ Tomato } \\
\hline 0.25 & $86 \pm 4 \%$ & $116 \pm 5 \%$ \\
0.50 & $99 \pm 4 \%$ & $101 \pm 4 \%$ \\
0.75 & $97 \pm 5 \%$ & $90 \pm 6 \%$ \\
1.00 & $94 \pm 3 \%$ & $90 \pm 5 \%$ \\
\hline
\end{tabular}

* with $5 \mathrm{ml}$ concentrated $\mathrm{HNO}_{3}$ and at $900 \mathrm{~W}$ for $35 \mathrm{~min}$.

Table 3 Effect of microwave powers on the recovery of spiked $10 \mu \mathrm{g} / \mathrm{l} \mathrm{As}(\mathrm{III})$ in chilli pepper and tomato samples.

\begin{tabular}{lcr}
\hline Microwave power (W) & Chilli pepper & \multicolumn{1}{c}{ Tomato $^{*}$} \\
\hline 700 & $111 \pm 3 \%$ & $95 \pm 2 \%$ \\
800 & $119 \pm 5 \%$ & $87 \pm 3 \%$ \\
900 & $98 \pm 2 \%$ & $100 \pm 1 \%$ \\
1000 & $93 \pm 4 \%$ & $87 \pm 5 \%$ \\
\hline
\end{tabular}

${ }^{*} 0.5 \mathrm{~g}$ sample in $5 \mathrm{ml}$ concentrated $\mathrm{HNO}_{3}$ and at 700$1000 \mathrm{~W}$ for $35 \mathrm{~min}$.

matrices which might affect the digestion efficiency by varying sample amount, microwave power and digestion time by a simple optimization method comparing its response in terms of recovery (\%) of the As content in selected real sample. The obtained results are shown in Tables 2-4. It was found that using $900 \mathrm{~W}$ microwave current for $35 \mathrm{~min}$ digestion time can be used for both tomato and chilli samples with $0.5 \mathrm{~g}$ sample weight and $5 \mathrm{ml}$ concentrated $\mathrm{HNO}_{3}$.

\section{Analytical performance}

The calibration curve and its regression equation obtained for both $\mathrm{As}(\mathrm{IIII})$ and $\mathrm{As}(\mathrm{V})$ standard solutions are shown in Table 5. The calibration graphs are linear up to a concentration of $10 \mu \mathrm{g} / \mathrm{l}$ for As(III) and $\mathrm{As}(\mathrm{V})$, but their linear analytical range for sample determination is selected between $1.0 \mu \mathrm{g} / \mathrm{l}$ and $5.0 \mu \mathrm{g} / \mathrm{l}$. The detection limits based on $3 \sigma / m$, where $\sigma$ is the standard deviation of 10 measurements of a blank and $m$ the slope of the calibration graphs, were $0.004 \mu \mathrm{g} / \mathrm{l}$ for $\mathrm{As}(\mathrm{III})$ and $0.006 \mu \mathrm{g} / \mathrm{l}$ for $\mathrm{As}(\mathrm{V})$.

Table 4 Effect of digestion times on the recovery of spiked $10 \mu \mathrm{g} / \mathrm{l} \mathrm{As}(\mathrm{III})$ in chilli pepper and tomato samples.

\begin{tabular}{lcr}
\hline Digestion time (min) & Chilli pepper & Tomato $^{*}$ \\
\hline 25 & $69 \pm 5 \%$ & $103 \pm 2 \%$ \\
30 & $73 \pm 6 \%$ & $107 \pm 2 \%$ \\
35 & $98 \pm 2 \%$ & $116 \pm 5 \%$ \\
40 & $89 \pm 5 \%$ & $84 \pm 5 \%$ \\
\hline$*$
\end{tabular}

* $0.5 \mathrm{~g}$ sample in $5 \mathrm{ml}$ concentrated $\mathrm{HNO}_{3}$ and at $900 \mathrm{~W}$.
Table 5 Analytical characteristics for both As(III) and As(V) determination under the optimized conditions of MAD and FI-HGAAS methods.

\begin{tabular}{lcc}
\hline Analytical characteristic & $\mathrm{As}(\mathrm{III})$ & $\mathrm{As}(\mathrm{V})$ \\
\hline Calibration equation & $y=0.0099 x$ & $y=0.0153 x$ \\
& +0.00007 & +0.0069 \\
Correlation coefficient $\left(r^{2}\right)$ & 0.9995 & 0.9988 \\
Linear analytical range $(\mu \mathrm{g} / \mathrm{l})$ & $1.0-5.0$ & $1.0-5.0$ \\
RSD $(\%, n=10)$ & 4.99 & 5.32 \\
Detection limit $(\mu \mathrm{g} / \mathrm{l})$ & 0.004 & 0.006 \\
\hline
\end{tabular}

Table 6 Recovery of spiked $10 \mu \mathrm{g} / \mathrm{l}$ of As(III), As(V) and total As in three chilli varieties.

\begin{tabular}{lcrr}
\hline Sample & As(III) & \multicolumn{1}{c}{ As(V) } & Total As \\
\hline Yodson Khem & $98 \pm 2 \%$ & $121 \pm 3 \%$ & $98 \pm 4 \%$ \\
Jindanil 80 & $98 \pm 5 \%$ & $91 \pm 5 \%$ & $107 \pm 2 \%$ \\
Super Hot & $93 \pm 5 \%$ & $105 \pm 4 \%$ & $84 \pm 4 \%$ \\
\hline
\end{tabular}

\section{Recovery study}

The recovery was studied by spiking each of $10 \mu \mathrm{g} / \mathrm{l}$ standard solution of As(III), As(V) and total As into the ground chilli and tomato samples. Under the optimized conditions for MAD, the recovery methods of As(III) found in both plant samples were obtained (Tables 2-4) as mentioned above. Emphasizing on some varieties of the hot chilli, the recoveries (\%) of As(III) for three kinds of the samples used were found in the range $93-98 \%$. Those of $\mathrm{As}(\mathrm{V})$ were ranged 91-122\% and total As were also investigated and found to be $84-107 \%$ as summarized in Table 6 . In this case, the method recovery study of which an ultratrace amount of each of standard solution of As(III) and $\mathrm{As}(\mathrm{V})$ was used to spike into the ground sample mixture. The variable ranges of the obtained results were still found due to difference in these sample matrices, although an organoarsenic species present in the plant samples was negligible.

\section{Real sample analysis}

The proposed method was applied for the trace determination of inorganic As species in hot chilli and tomato samples under the optimum conditions for MAD and FI-HGAAS. The contents of both As(III) and $\mathrm{As}(\mathrm{V})$ including total As in six varieties of hot chilli and seven varieties of tomato are summarized in Table 7 and Table 8, respectively. The contents of As(III), As(V) and total arsenic in chilli samples were in the range $0.547-0.878 \mu \mathrm{g} / \mathrm{g}, 0.219-0.930 \mu \mathrm{g} / \mathrm{g}$ and $0.766-1.58 \mu \mathrm{g} / \mathrm{g}$, respectively. And those of As(III), $\mathrm{As}(\mathrm{V})$ and total arsenic in tomato samples were in the range $0.358-0.637 \mu \mathrm{g} / \mathrm{g}, 0.218-0.596 \mu \mathrm{g} / \mathrm{g}$ and $0.583-$ 
Table 7 The contents of inorganic As species $(\mu \mathrm{g} / \mathrm{g})$ in some chilli varieties (mean $\pm \mathrm{SD} ; n=5$ ).

\begin{tabular}{lccc}
\hline Sample & As(III) & As(V) & Total As \\
\hline Jindanil 80 & $0.79 \pm 0.08$ & $0.38 \pm 0.20$ & $1.17 \pm 0.25$ \\
Super Hot & $0.55 \pm 0.06$ & $0.22 \pm 0.06$ & $0.77 \pm 0.09$ \\
Yodson Khem 80 & $0.65 \pm 0.17$ & $0.30 \pm 0.18$ & $0.96 \pm 0.29$ \\
Numkaew Thong 80 & $0.88 \pm 0.17$ & $0.25 \pm 0.11$ & $1.12 \pm 0.17$ \\
Yodson Korat & $0.76 \pm 0.09$ & $0.63 \pm 0.17$ & $1.39 \pm 0.20$ \\
Huay Sithon & $0.65 \pm 0.07$ & $0.93 \pm 0.34$ & $1.58 \pm 0.32$ \\
\hline
\end{tabular}

Table 8 The contents of inorganic As species $(\mu \mathrm{g} / \mathrm{g})$ in some tomato varieties (mean $\pm \mathrm{SD} ; n=5$ ).

\begin{tabular}{lccc}
\hline Sample & As(III) & As(V) & Total As \\
\hline PD 09 & $0.36 \pm 0.06$ & $0.23 \pm 0.17$ & $0.59 \pm 0.12$ \\
PS 07 & $0.55 \pm 0.14$ & $0.22 \pm 0.10$ & $0.76 \pm 0.20$ \\
GD & $0.64 \pm 0.18$ & $0.60 \pm 0.27$ & $1.23 \pm 0.45$ \\
Cherry Kham Kaen & $0.41 \pm 0.11$ & $0.32 \pm 0.10$ & $0.73 \pm 0.07$ \\
Puang Thong & $0.41 \pm 0.20$ & $0.34 \pm 0.19$ & $0.75 \pm 0.05$ \\
Morrakot Daeng & $0.36 \pm 0.16$ & $0.23 \pm 0.16$ & $0.58 \pm 0.15$ \\
\hline
\end{tabular}

\section{$1.233 \mu \mathrm{g} / \mathrm{g}$, respectively.}

In conclusion, highly sensitive and simple method for the determination of inorganic As species by FIHGAAS was obtained. The method exhibited very low detection limit of $0.006 \mathrm{ng} / \mathrm{l}$ and limit of quantitation of $0.022 \mathrm{ng} / \mathrm{l}$. The calibration curve of As was linear in the range 1.0-5.0 $\mu \mathrm{g} / \mathrm{l}$ with an $r^{2}>0.999$. This method was then applied for the determination of As(III), As(V) and total arsenic in some hot chilli and tomato samples after an optimized sample preparation MAD. The MAD method with small amount of $0.5 \mathrm{~g}$ sample and $5 \mathrm{ml}$ concentrated $\mathrm{HNO}_{3}$ gave faster, more safe, and accurate results. The proposed analytical method was successfully applied to determine As in these economic plant samples.

Acknowledgements: This study was supported by the Higher Education Research Promotion and National Research University Project of Thailand, Office of the Higher Education Commission, through the Food and Functional Food Research Cluster of Khon Kaen University. The Centre of Excellence for Innovation in Chemistry (PERCHCIC), Commission on Higher Education, Ministry of Education is also gratefully acknowledged.

\section{REFERENCES}

1. Glanze WD (1996) Mosby Medical Encyclopedia, revised edition. C.V. Mosby, St. Louis, MO.

2. International Labour Organisation (1998) Metals. In: Basics of Chemical Safety, Module 7, International Programme on Chemical Safety, ILO, United Nations, Geneva.

3. Meharg AA, Hartley-Whitaker J (2002) Arsenic uptake and metabolism in arsenic resistant plant species. New Phytol 154, 29-43.

4. Francesconi K, Visoottiviseth $\mathrm{P}$, Sridokchan W, Goessler W (2002) Arsenic species in an arsenic hyperaccumulating fern, Pityrogramma calomelanos: a potential phytoremediator of arsenic-contaminated soils. Sci Total Environ 284, 27-35.

5. Koch I, Wang L, Ollson CA, Cullen WR, Reimer KJ (2000) The predominance of inorganic arsenic species in plants from Yellowknife, Northwest Territories, Canada. Environ Sci Tech 34, 22-6.

6. Mattusch J, Wennrich R, Schmidt AC, Reisser W (2000) Determination of arsenic species in water, soils and plants. Fresen J Anal Chem 366, 200-3.

7. Banejad H, Olyaie E (2011) Arsenic toxicity in the irrigation water-soil-plant system: a significant environmental problem. J Am Sci 7, 125-31.

8. Quaghebeur M, Rengel Z (2003) The distribution of arsenate and arsenite in shoots and roots of Holcus lanatus is influenced by arsenic tolerance and arsenate and phosphate supply. Plant Physiol 132, 1600-9.

9. Tuzen M, Sarı A, Mendil D, Uluozlu OD, Soylak M, Dogan M (2009) Characterization of biosorption process of As(III) on green algae Ulothrix cylindricum. $J$ Hazard Mater 165, 566-72.

10. Sar1 A, Tuzen M (2009) Biosorption of As(III) and $\mathrm{As}(\mathrm{V})$ from aqueous solution by macrofungus (Inonotus hispidus) biomass: Equilibrium and kinetic studies. J Hazard Mater 164, 1372-8.

11. Sar1 A, Tuzen M (2010) Biosorption of As(III) and $\mathrm{As}(\mathrm{V})$ from aqueous solution by lichen (Xanthoria parietina) biomass. Separ Sci Tech 45, 463-71.

12. Sarı A, Uluozlü OD, Tüzen M (2011) Equilibrium, thermodynamic and kinetic investigations on biosorption of arsenic from aqueous solution by algae (Maugeotia genuflexa) biomass. Chem Engineer J 167, 15561.

13. Shah AQ, Kazi TG, Baig JA, Arain MB, Afridi HI, Kandhro GA, Wadhwa SK, Kolachi NF (2010) Determination of inorganic arsenic species $\left(\mathrm{As}^{3+}\right.$ and $\mathrm{As}^{5+}$ ) in muscle tissues of fish species by electrothermal atomic absorption spectrometry (ETAAS). Food Chem 119, 840-4.

14. Curros-Gontad B, Barciela-Alonso MC, Buján-Villar MD, Peña-Vázquez E, Herbello-Hermelo P, BermejoBarrera P (2008) Study of a microwave digestion method for total arsenic determination in marine mussels by electrothermal atomic absorption spectrometry: application to samples from the Ria de Arousa. Eur Food Res Tech 227, 1165-72.

15. Contreras-Padilla M, Yahia EM (1998) Changes in capsaicinoids during development, maturation, and senescence of chile peppers and relation with peroxidase activity. J Agr Food Chem 46, 2075-9.

16. Antonious GF, Kochhar TS (2009) Mobility of heavy metals from soil into hot pepper fruits: a field study. Bull Environ Contam Toxicol 82, 59-63. 
17. Ruiz-Chancho MJ, Sabé R, López-Sánchez JF, Rubio R, Thomas P (2005) New approaches to the extraction of arsenic species from soils. Microchim Acta 151, 241-8.

18. D’Ulivo A, Gianfranceschi L, Lampugnani L, Zamboni $\mathrm{R}$ (2002) Masking agents in the determination of selenium by hydride generation technique. Spectrochim Acta B 57, 2081-94.

19. Frank J, Krachler M, Shotyk W (2005) Direct determination of arsenic in acid digests of plant and peat samples using HG-AAS and ICP-SF-MS. Anal Chim Acta 530, 307-16.

20. Tuzen M, Saygi KO, Karaman I, Soylak M (2010) Selective speciation and determination of inorganic arsenic in water, food and biological samples. Food Chem Toxicol 48, 41-6.

21. Yang LL, Gao LR, Zhang DQ (2003) Speciation analysis of arsenic in traditional Chinese medicines by hydride generation-atomic fluorescence spectrometry. Anal Sci 19, 897-902. 